\title{
Cellular localization and changes in expression of prolactin receptor isoforms in sheep ovary throughout the estrous cycle
}

\author{
R A Picazo, J P García Ruiz ${ }^{1}$, J Santiago Moreno², A González de Bulnes ${ }^{2}$, J Muñoz ${ }^{1}$, G Silván, \\ P L Lorenzo and J C Illera \\ Departamento de Fisiología Animal, Facultad de Veterinaria, Universidad Complutense, 28040-Madrid, \\ ${ }^{1}$ Departamento de Bioquímica y Biología Molecular, Centro de Biología Molecular Severo Ochoa, Facultad de \\ Ciencias, Universidad Autónoma de Madrid and ${ }^{2}$ Departamento de Reproducción y Conservación de Recursos \\ Zoogenéticos, Avda. Puerta de Hierro sn, 28040-Madrid
}

Correspondence should be addressed to R A Picazo; Email: rapicazo@vet.ucm.es

\begin{abstract}
The actions of prolactin (PRL) on target cells depend on the type of prolactin receptor (PRLr) predominantly expressed, particularly whether the long PRLr isoform is expressed. The aims of this study were to determine the cellular localization and the changes in expression of long and short PRLr isoforms in sheep ovary throughout the estrous cycle. Long and short PRLrs were localized mostly in the same ovarian cells. Maximum signal intensity, particularly for long PRLrs, was found in stromal cells surrounding primordial and primary follicles, and, for both PRLrs, in granulosa cells of preantral follicles and in luteal cells. Moderate signal intensity for PRLrs was found in theca cells of preantral to ovulatory follicles, and in granulosa cells of antral follicles up to the gonadotropin-dependent stage. Decreasing immunoreactivity to PRLrs was found in granulosa cells of gonadotropin-dependent to ovulatory follicles. For long PRLrs in particular, no signal was found in mural granulosa cells of gonadotropin-dependent follicles; for both isoforms, no signal was found in most granulosa cells of ovulatory follicles.

In primordial to gonadotropin-dependent follicles, cellular localization of PRLr was similar on days 0, 10 and 15 of the cycle. Oocytes consistently showed positive immunostaining for PRLrs. Comparative RT-PCR analysis of long and short PRLr expression showed that the short isoform is evenly expressed throughout the estrous cycle, whereas the expression of the long form increases at the time of estrus and decreases at mid-luteal phase and at the onset of the follicular phase. Expression of long PRLrs was greater than that of short PRLrs on day 0 of cycle; expression of both isoforms was similar on day 10 and on day 15, long PRLrs expression was lower than that of short PRLrs. Our results indicate that in sheep ovary, the maximum responsiveness to PRL might occur during the preovulatory phase of the estrous cycle.

Reproduction (2004) 128 545-553
\end{abstract}

\section{Introduction}

Prolactin (PRL), a peptide hormone produced by the pituitary gland and extrapituitary tissues (Ben-Jonathan et al. 1996), is a key regulator of reproduction in mammals, as demonstrated with the null mutant PRL receptor (PRLr) mouse model (Ormandy et al. 1997). Male and female PRLr knockout mice exhibit multiple reproductive defects, and are infertile. In particular, homozygous females are sterile: they ovulate a reduced number of oocytes that are mostly immature; they show low fertilization rates, an arrest of embryo development, altered oviduct microenvironment and a uterus refractory to implantation. In addition, these females have a markedly reduced number of primary follicles in the ovaries, indicating that PRL is a key inducer of the onset of follicular development. PRL is a modulator of cell proliferation and differentiation (Ben
Jonathan et al. 1996), whereby it might play a role in ovarian follicular growth. In granulosa cells, PRL can inhibit or stimulate estradiol (McNeilly et al. 1982, Tsai-Morris et al. 1983, Jonassen et al. 1991) and progesterone (Veldhuis et al. 1980, Jones et al. 1983, Yoshida 1987) secretion respectively by activating distinct signaling pathways in a differentiation-dependent fashion (Russell \& Richards 1999). PRL acts in synergism with follicle-stimulating hormone ( $\mathrm{FSH}$ ) to stimulate granulosa cell proliferation (Roy \& Greenwald 1988) and it promotes ovarian follicular development, which advances the onset of puberty in rats (Kawagoe \& Hiroi 1989, Peluso 1989, Advis et al. 1981). In the corpus luteum, PRL can be luteotropic in sheep (Denamur et al. 1973) and rat (Gibori 1992), and, at least in rat, also luteolytic (Matsuyama et al. 1996). Luteinizing hormone (LH) receptor expression is 
up-regulated by PRL in pseudopregnant rat corpus luteum (Bjurulf et al. 1994) and down-regulated in ovarian follicles of lactating rabbits (Kermabon et al. 1994), which may account for the luteotropic and anovulatory effects of the hormone respectively.

PRL exerts its actions by binding to specific membrane receptors. Long, short and intermediate isoforms of PRLr (Goffin et al. 1999) encoded by a single gene and produced by alternative splicing (Bignon et al. 1997) have been described to date, and are widely expressed in animal tissues. When reaching the target cell, one molecule of PRL binds to two molecules of PRLr. However, most experimental evidence has shown that only binding of PRL to homodimers of the long isoform can induce proliferative or differentiative cell responses. A few studies (Das \& Vonderhaar 1995) have shown that binding to heterodimers, or to homodimers of the short isoform, silences the actions of PRL (Chang \& Clevenger 1996, Berlanga et al. 1997, Perrot-Applanat et al. 1997). Therefore, it is generally accepted that a correlation exists between being a target of PRL actions and the expression of the long PRLr isoform. To date, development-related variations in localization and expression of these two PRLrs in ovarian granulosa and theca cells throughout the estrous cycle have only been fully described in the rat (Clarke et al. 1993, Nagano \& Kelly 1994). In red deer ovary, expression of the PRLr gene was localized to the corpus luteum and theca cells of follicles, with no variations throughout the reproductive cycle (Clarke et al. 1997); this suggests that PRL actions in the ovary might differ among species. The sheep is an ideal animal model for studying the actions of PRL on ovarian follicular development, since this species exhibits stable and predictable periods of increased plasma PRL concentrations during its annual reproductive cycle, that can be manipulated exogenously and correlated with ovarian follicular dynamics; in addition, sheep ovarian follicles are well characterized in terms of size, hormone responsiveness and state of granulosa and theca cell differentiation (Scaramuzzi et al. 1993) for in vitro studies. In sheep, mRNAs for long and short PRLr isoforms have been found in the ovary (Anthony et al. 1995); the isoforms only differ by the presence of a $39 \mathrm{bp}$ insert at the beginning of the cytoplasmic domain of the short isoform, and encode the synthesis of 557- and 272-amino acid proteins for long and short isoforms respectively (Bignon et al. 1997). The possible variations in the expression of long and short PRLrs, and their cellular localization in different follicle populations throughout the estrous cycle in sheep ovary, are currently unknown. Therefore, in order to elucidate the potential variations in cellular responsiveness to PRL in sheep ovary, we considered it of interest to localize PRLr isoforms in ovaries of adult ewes by immunohistochemistry, and to compare their expression by RT-PCR at three representative time points of the estrous cycle.

\section{Material and Methods}

\section{Animals}

Twelve adult, cycling, and non-lactating Merino ewes (Ovis aries) were used in this study. Animals were housed in the farm building of Instituto Nacional de Investigaciones Agrarias in Madrid ( $\left.40^{\circ} 25^{\prime} \mathrm{N}\right)$. They were kept outdoors under a natural lighting regimen with free access to indoor facilities; they were fed grass pellets, commercial feed and hay, and water was freely available. All procedures followed the European Community Council Directive 86/609/CEE (18 February 1986) that regulates the protection of animals used in experimentation. In January, ewes were assessed for cyclicity by laparoscopy 2 weeks before the onset of the experiment. Estrous was then synchronized with two $125 \mu \mathrm{g}$ cloprostenol injections (Estrumate 7, Essex Animal Health, Friesoythe, Germany) given 10 days apart. After the second injection, estrous was detected every $6 \mathrm{~h}$, with the aid of vasectomized rams fitted with coloured harnesses. Ovariectomies were performed on days 0 (time of estrus; $n=4$ ), 10 (midluteal phase; $n=4$ ) and 15 (early follicular phase; $n=4$ ) of the estrous cycle. In brief, ewes were anaesthetized with a combination of ketamine (Imalgene, Rhone Merieux, France) and xylazine (Rompún, Bayer). After laparotomy, ovaries were excised, longitudinally sectioned and immediately processed. Half of each ovary was processed for immunohistochemistry and the remaining two halves were immediately frozen in liquid nitrogen, and subsequently stored at $-80^{\circ} \mathrm{C}$ until RNA extraction.

\section{Immunohistochemistry}

Samples were fixed in Bouin solution for $12 \mathrm{~h}$, then placed in $40 \%$ ethanol for $24 \mathrm{~h}$ and subsequently embedded in paraffin. Immunostaining was performed on $4 \mu \mathrm{m}$ serial sections placed onto poly-L-lysine (Sigma)-coated glass slides, following a standard procedure; this comprised quenching of endogenous peroxidase, blocking nonspecific binding with $1.5 \%$ normal goat serum and incubation with primary antibodies against short and long rat PRLr (1:600, in blocking buffer) for $2 \mathrm{~h}$, followed by 30 min incubation in secondary antibody (goat antirabbit immunoglobulins; Novocastra Laboratories Ltd, Newcastle upon Tyne, UK) and 30 min incubation in avidin-biotin complex (Novocastra Laboratories Ltd). After detection with diaminobenzidine (Sigma), sections were counterstained with haematoxylin, dehydrated, cleared and mounted with non-aqueous mounting medium (Permount; Fisher Scientific, NJ, USA). All incubations were done in humidified chambers at laboratory temperature.

Antibodies raised in rabbits against long (R118) and short (R133) rat PRLrs were kindly donated by Dr Ingleton (Institute of Endocrinology, Sheffield University, UK) and had been specifically produced against residues 309-325 and 281-296 of the intracellular regions of long and short rat PRLrs respectively. These antibodies had been 
previously tested to specifically recognize long and short sheep PRLrs by immunohistochemical and immunoblotting techniques (Tortonese et al. 1998, Bispham et al. 1999, Budge et al. 2000, 2003).

Sections of adult cycling rat ovaries were used as positive controls. In the negative control sections, incubation with primary antibodies was replaced by blocking buffer with normal rabbit serum (1:600), or blocking buffer or Tris buffer solution. Sections were analysed and photographed under the light microscope, and the intensity of positive staining within each slide was depicted as weak $(+)$, moderate $(++)$ or strong $(+++)$. No comparison of staining intensity was done between different tissue sections to avoid misinterpretations caused by slight differences in incubation times. Therefore, intensities of staining cannot be compared between days 0,10 and 15 of the estrous cycle.

\section{RNA extraction and comparative RT-PCR}

Total RNA was individually extracted from the ovaries of each ewe, using a phenol-m-cresol method (Zabala \& García-Ruiz 1989) in which incubation of nucleic acids with lithium chloride allowed elimination of DNA in samples. RNA $(5 \mu \mathrm{g})$, random primers $\left(1 \mu \mathrm{l}, 0.5 \mu \mathrm{g} ; \mathrm{pd}(\mathrm{N})_{6}\right.$ random hexamer; Amersham) and water were mixed up to a final volume of $7 \mu \mathrm{l}$, and incubated in a water-bath at $95^{\circ} \mathrm{C}$ for 5 min. In blank control tubes, RNA was replaced by PCR water. Then, RT buffer $5 \times(2 \mu \mathrm{l} / \mathrm{sample})$, dNTPs $(0.5 \mu \mathrm{l} / \mathrm{sample}, 10 \mathrm{mM}$; Amersham) and reverse transcriptase $(0.5 \mu \mathrm{l} /$ sample; AMV reverse transcriptase, $15 \mathrm{U} / \mu \mathrm{l}$, USB Corporation, $\mathrm{OH}$, USA) were added to denatured RNA samples (final volume $10 \mu \mathrm{l} / \mathrm{sample}$ ) which were then incubated at $42{ }^{\circ} \mathrm{C}$ for $60 \mathrm{~min}$ in a water-bath for DNA synthesis. Sheep PRLr isoforms were amplified using the following primers: a sense oligonucleotide from the coding region common to long and short PRLr mRNAs (forward) 5'-CGATGCAAGCCAGACCATG-3' (+640 to +658 ) and two different antisense primers specific for long (reverse) 5'-TGGTCCTCACTGTCATCTAC-3' $(+1020$ to $+1039,342 \mathrm{bp}$ fragment, accession number AF041257, Bignon et al. 1997) and short PRLr mRNA (reverse) 5'-CAAGGCGAGAAGGCTGTG-3' (+861 to +878, 265 bp fragment, accession number AF041977, Bignon et al. 1997). For amplification of ovine actin, used as control for internal normalization, primers used were: 5'-GCACCACCATGTACCCTG-3' (forward) (+3 to +20 ), 5'-CATCTGCTGGAAGGTGGAC-3' (reverse) (+145 to +163 , 161 bp fragment, accession number U08283, Bacich et al. 1994). Oligonucleotides were used at a final working concentration of $12.5 \mathrm{pmol} / \mu \mathrm{l}$. In each PCR reaction tube, DNA template $(1 \mu \mathrm{l}$ for long and short PRLrs, $0.5 \mu \mathrm{l}$ for ovine actin), $1 \mu \mathrm{l}$ sense primer, $1 \mu \mathrm{l}$ antisense primer, $1 \mu \mathrm{l} 10 \mathrm{mM}$ dNTPs, $5 \mu \mathrm{l} 10 \times$ PCR buffer, $6 \mu \mathrm{l}$ $25 \mathrm{mM} \mathrm{MgCl} 2,0.5 \mu \mathrm{l} \mathrm{Taq}$ polymerase (10 UI/ $\mu \mathrm{l}$; Promega), $5 \mu \mathrm{l}$ DMSO (only for short PRLrs) and PCR-quality water $(34.5 \mu \mathrm{l}$ or $29.5 \mu \mathrm{l}$ for long and short PRLrs respectively) were mixed. Products of reverse transcription with no
RNA, and PCR reaction mix with water instead of DNA, were included in each PCR run as negative controls. Sheep corpus luteum DNA synthesized from total RNA extracted simultaneously with experimental samples was used as positive control. After $5 \mathrm{~min}$ at $94^{\circ} \mathrm{C}$, amplification was carried out for 35 cycles of $1 \mathrm{~min}$ at $94^{\circ} \mathrm{C}, 2 \mathrm{~min}$ at $55^{\circ} \mathrm{C}$ and $3 \mathrm{~min}$ at $72{ }^{\circ} \mathrm{C}$ for short PRLrs - and 35 cycles of $1 \mathrm{~min}$ at $94^{\circ} \mathrm{C}, 2 \mathrm{~min}$ at $52^{\circ} \mathrm{C}$ and 3 min at $72^{\circ} \mathrm{C}$ for long PRLrs - followed in both cases by $7 \mathrm{~min}$ at $72^{\circ} \mathrm{C}$, and temperature lowering to $4{ }^{\circ} \mathrm{C}$, in a thermal cycler (Perkin Elmer, Gene Amp PCR System 2400). PCR products $(16 \mu \mathrm{l} / \mathrm{sample})$ were electrophoresed in $2 \%$ agarose gel (Gibco) in Tris borate EDTA buffer. Gels were stained with ethidium bromide, and photographed under u.v. light. Photographs were scanned and the optical density of each individual DNA band was determined in a densitometer (GS-710, Calibrated Imaging Densitometer, BioRad). The identity of each DNA fragment was confirmed by automatic sequencing (ABI PRISM dye terminator cycle sequencing ready reaction kit, Perkin Elmer).

\section{Statistical analysis}

The optical density of each long and short PRLr DNA fragment was normalized by the corresponding optical density of each actin DNA fragment. Differences in normalized optical densities of long or short PRLr DNA bands over the three phases of the estrous cycle were then assessed by one way-ANOVA. One way-ANOVA was also used to compare mean normalized optical densities of long and short PRLr DNA within each time point (preovulatory, mid-luteal and early follicular phase). $P<0.01$ or $P<0.05$ was considered statistically significant.

\section{Results \\ Cellular localization of PRLr in sheep ovary throughout the estrous cycle}

We looked at the cellular localization of PRLr isoforms in sheep ovary on days 0,10 and 15 of the estrous cycle with the aid of specific antibodies for long and short PRLrs, in order to find out if there were variations in their localization during estrus, mid-luteal and early follicular phases respectively. Representative photomicrographs of ovary sections immunostained with antibodies for long and short PRLrs are shown in Figs 1 and 2 respectively. Image analysis of tissue sections revealed that, apart from a few differences, long and short PRLrs were localized in the same cell types, which indicated their coexpression. Therefore, unless otherwise stated, we will refer to PRLrs. We found first that, in primordial, preantral and antral follicles up to the gonadotropin-dependent stage $(4-5 \mathrm{~mm})$, the cellular localization of PRLrs was the same on days 0,10 and 15 of the estrous cycle, when these follicles are invariably found. A consistent finding was that, regardless of the day of the cycle and the follicular developmental stage, oocytes exhibited positive signals for 

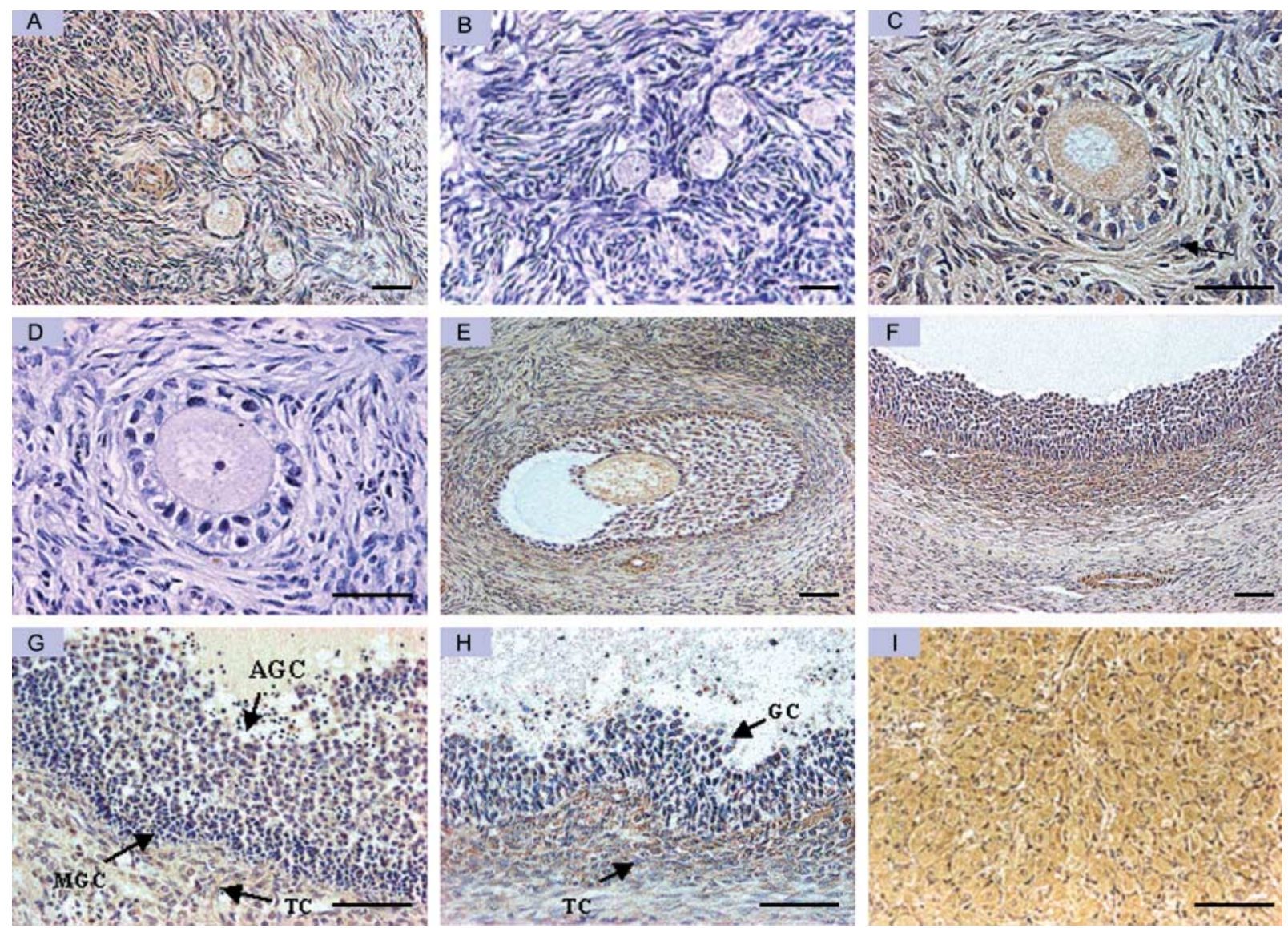

Figure 1 Photomicrographs of ewe ovary sections immunostained with antibody against the long isoform of PRLr (R118). (A) Group of primordial follicles in cortex of an ewe ovary $(\times 20 / 0.70)$, showing positive staining (brown) in oocytes and in many surrounding stromal cells. (B) Negative control. (C) Primary to secondary follicle $(\times 2 \times 40 / 0.75)$ showing positive staining in most granulosa cells and stromal cells (arrow), some negative granulosa cells (blue), and negative control (D). (E) Early antral follicle ( $\times 20 / 0.70)$ showing consistently positive staining in granulosa and theca cells. (F) Detail of the wall $(\times 20 / 0.70)$ of a gonadotrophin-responsive follicle showing positive staining for PRLr in both granulosa and theca cells. $(G)$ Detail of the wall $(\times 40 / 0.75)$ of a follicle reaching the gonadotrophin-dependent stage $(4 \mathrm{~mm})$, showing positive staining in theca cells (TC) and in most antral granulosa cells (AGC), whereas mural granulosa cells (MGC) are mostly negative. (H) Ovulatory follicle $(5 \mathrm{~mm}$; day 0 of cycle) $(\times 40 / 0.75)$ showing positive theca cells (TC) and most granulosa cells (GC) negative. (I) Section of a corpus luteum ( $\times 40 / 0.75$ ) showing positive immunostaining in all luteal cells. Scale bars of a, b, e, f represent $30 \mu \mathrm{m}$; c, d represent $22 \mu \mathrm{m}$; g, h, i represent $45 \mu \mathrm{m}$.

PRLrs. Interestingly, we observed remarkable variations in localization of PRLrs as follicles developed from the primordial stage to the attainment of the ovulatory size. Immunoreactivity for PRLrs appeared in stromal cells that surround primordial follicles, being particularly intense and even for long PRLr $(+++)$ (Fig. 1A). Even though pregranulosa cells from primordial follicles appeared to show immunoreactivity for PRLRs, the flattened morphology of these cells made this difficult to clearly establish; however, in primary follicles, once pregranulosa cells had differentiated into a single layer of cubical cells, most of them showed strong positive staining $(+++)$ for PRLrs (Figs 1C and 2A). PRLrs were localized in stromal cells that surround primary follicles during their migration towards the inner part of the ovarian cortex, with moderate $(++)$ or strong $(+++)$ intensity of staining (Figs $1 \mathrm{C}$ and 2A). Long PRLr was more evenly localized than short PRLr in these cells. During the preantral phase of follicular development (from 1 to $10-12$ granulosa cell layers), granulosa cells uniformly showed the most intense signals $(+++)$ for PRLrs in follicles with 2 to $5-6$ granulosa cell layers, and moderate-intensity staining $(++)$ in follicles with more than 6 cell layers, up to antrum formation. Also in preantral follicles, positive staining for PRLrs was seen in theca interna, from the time these cells became organized around granulosa $(+)$, which was coincident with the presence of 5-6 granulosa cell layers, and increased $(++)$ as theca interna cells proliferated to form a developed layer.

During antrum formation, both granulosa $(++)$ and theca $(++)$ cells were positive for PRLrs (Fig. 1E). Once an antrum was formed, granulosa and theca cells were uniformly positive $(++)$ until the follicles had reached about $2 \mathrm{~mm}$ in diameter (Figs $1 \mathrm{~F}$, and 2D and $\mathrm{E}$ ). Remarkably, as follicles grew beyond $2 \mathrm{~mm}$ in diameter, and in particular in $3-4 \mathrm{~mm}$ follicles, theca cells 

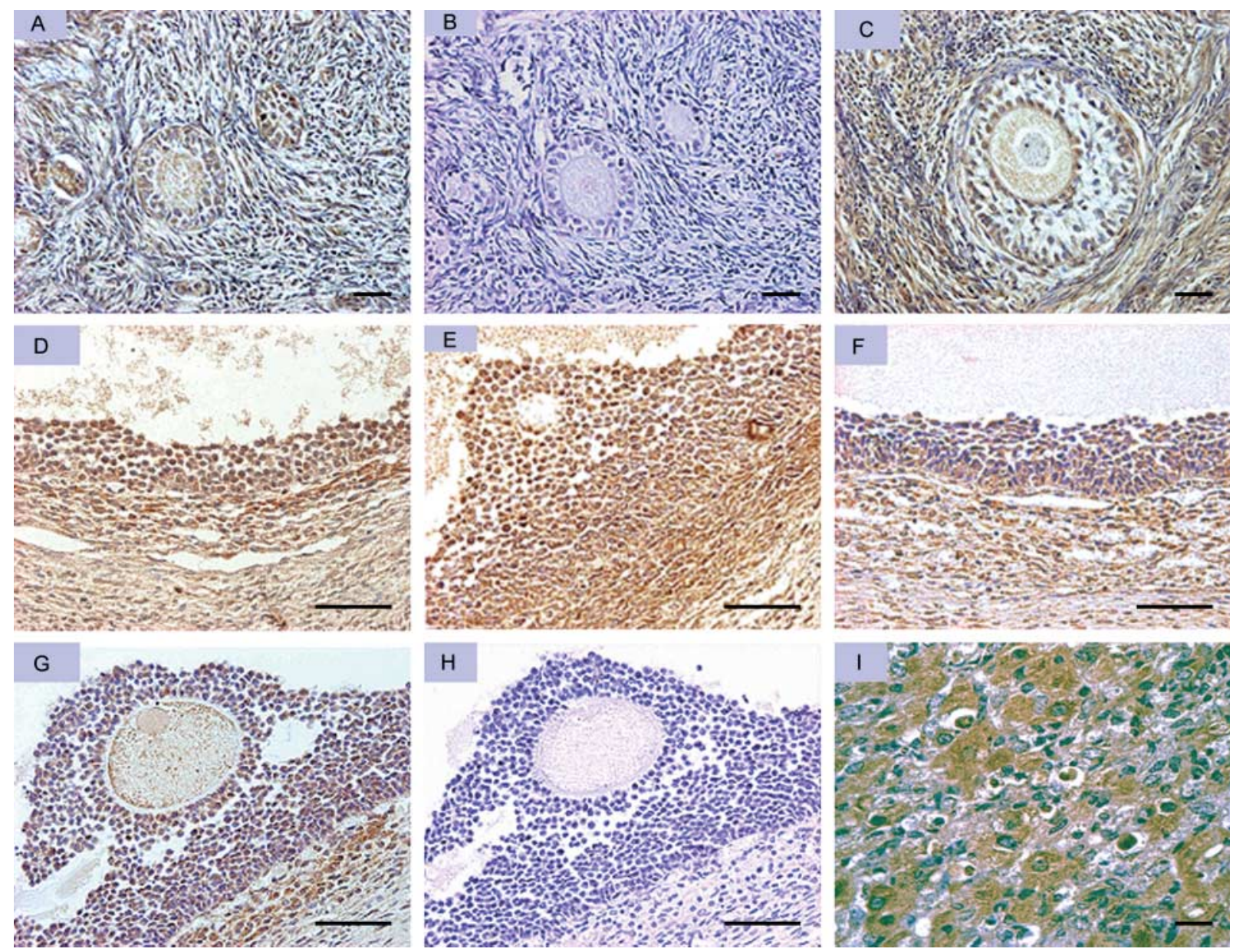

Figure 2 Photomicrographs of ewe ovary sections immunostained with antibody against the short isoform of PRLr (R133) showing (A) two primary follicles ( $\times 20 / 0.70$ ) with strongly positive (brown) granulosa cells and oocytes, surrounded by positive, and some negative (blue) stromal cells, and (B) negative control. (C) Preantral follicle ( $\times 20 / 0.70)$ with positive granulosa cells surrounded by positive and some negative stromal cells. (D) Detail of the wall of a gonadotropin-responsive follicle $(\times 40 / 0.75)$ showing strongly positive granulosa and theca cells, and $(E)$ cumulus area of the same follicle. (F) Detail of the wall of a follicle reaching the gonadotropin-dependent stage $(4 \mathrm{~mm}$; $\times 40 / 0.75)$, showing loss of immunoreactivity to short PRLr in granulosa cells, and positive theca cells. (G) Detail of cumulus area of an ovulatory follicle $(\times 40 / 0.75)$ with positive theca cells, some positive granulosa cells, many negative cells and $(\mathrm{H})$ negative control. (I) Section of a corpus luteum $(\times 2 \times 40 / 0.75)$ showing positive immunostaining in all luteal cells. Scale bars of a, b, c represent $30 \mu \mathrm{m}$; d, e, f, g, h represent $45 \mu \mathrm{m}$; i represents $45 \mu \mathrm{m}$.

remained positive $(++)$ whereas granulosa cells exhibited decreased immunoreactivity for PRLrs, with predominant loss of signal for long PRLrs in mural cells (Fig. 1G) and scattered signal loss for short PRLrs in antral and mural granulosa cells (Fig. 2F).

PRLr immunoreactivity in granulosa cells decreased even more in ovulatory follicles $(\geq 6 \mathrm{~mm}$, day 0 of the estrous cycle) where most antral granulosa cells had no signal for PRLrs (Fig. 1H), and only some cumulus granulosa cells and theca cells stained positively for PRLrs. Luteal cells in the corpus luteum (day 10 of the cycle) stained positively $(+++)$ for PRLrs (Figs $1 \mathrm{I}$ and $2 \mathrm{I}$ ). Thus, maximum potential responsiveness to PRL occurs in stromal and granulosa cells at the initial stages of follicular development, and it becomes moderate in granulosa and theca cells during antral development, with decreased immunoreactivity to PRLrs in granulosa cells as the follicle grows to attain ovulatory size.

\section{Expression of long and short PRLr isoforms in sheep ovary throughout the estrous cycle}

We assessed whether there are differences in the expression of long and short PRLrs over days 0,10 and 15 of the estrous cycle by comparative RT-PCR. We used total RNA extracted from the ovaries of each ewe; the results are summarized in Fig. 3. There were no differences in the expression of short PRLr in the preovulatory, mid-luteal and early follicular phases of the estrous cycle. In contrast, the expression of long PRLr markedly increased $(P<0.01)$ at estrus, when compared with expression at the mid-luteal and early follicular phases. At the early follicular phase, long PRLr expression was 


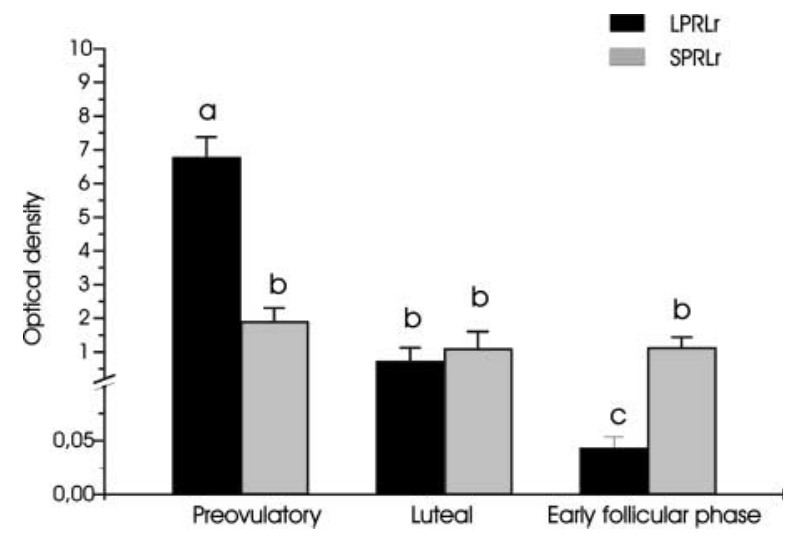

Figure 3 Changes in expression of long (black bars) and short (grey bars) PRLrs in sheep ovary at three time points throughout the estrous cycle (preovulatory, mid-luteal and early follicular phase). Each bar represents mean \pm S.E.M. of four individual ratios of the optical density of amplified DNA bands for long or short PRLrs and its corresponding actin optical density. Optical density is presented in arbitrary units. Different letters denote significant differences $(P<0.01 ; P<0.05)$.

even lower $(P<0.05)$ than in the mid-luteal phase. When comparing the expression of both isoforms on each day of cycle, we found that long PRLr expression was greater $(P<0.01)$ than that of short PRLr on day 0 , similar on day 10 , and lower $(P<0.05)$ on day 15 of the cycle. Even though the analysis performed is comparative, our results indicate that in sheep ovary long PRLr is predominantly expressed around the time of estrus; the results suggest that this might be the time of highest responsiveness to PRL. Representative results are presented in Fig. 4.

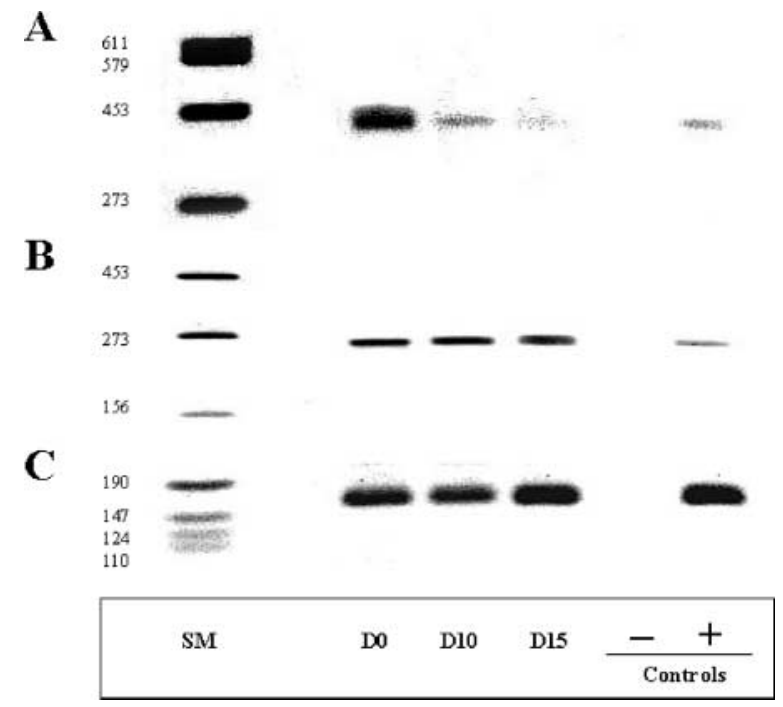

Figure 4 Representative results of PCR amplification of DNA fragments corresponding to long $(A)$ and short (B) PRLr, from a ewe on day 0 (lane $1 ; \mathrm{D} 0$, time of estrus), day 10 (lane 2; D10, mid-luteal phase) and day 15 (lane 3; D15, early follicular phase); negative control (lane 4, -), positive control (lane $4 ;+$, corpus luteum), size marker (lane 0; SM), and bands corresponding to amplified actin DNA fragments $(\mathrm{C})$.

\section{Discussion}

This study reports on the changes in expression of long and short PRLrs, and their cellular localization throughout the estrous cycle in the sheep ovary, the second species in which this has been described. Results indicate that the expression of each PRLr isoform is regulated independently. There were marked variations in expression of long PRLr, which predominated at the time of estrus, and similar expression of the short PRLr at the time of estrus, at the mid-luteal phase and at the early follicular phase. Cellular localization of PRLrs was most abundant in stromal and granulosa cells at the initial stages of follicular growth, it decreased in the granulosa cells of gonadotropin-dependent follicles, and was absent in granulosa cells of ovulatory follicles.

Maximum potential responsiveness to PRL in sheep ovary occurs at the initial stages of follicle growth. The most intense localization signals were found in stromal cells surrounding primordial follicles and in those accompanying primary follicles during their migration, once development has begun. Ovarian stromal cells synthesize enzymes that cleave the extracellular matrix (Riley et al. 2001, Song et al. 2001, Kiziridou et al. 2002). Some products of extracellular matrix breakdown induce cell migration (Wiseman \& Werb 2002), whereby stromal cells might modulate follicle mobility during early follicular development. It would be of interest to determine whether PRL influences this process by acting on stromal cells, which from our results appear to be highly responsive to PRL. Reported effects of PRL on the activity of these enzymes in the ovary are restricted to granulosa cells of preovulatory follicles, and are inhibitory (Yoshimura et al. 1990, Murray et al. 1996) whereas in other tissues PRL stimulates the synthesis of plasminogen activator (Buckley et al. 1984, 1985).

Our results show that synthesis of PRLrs in granulosa cells takes place for the first time in primordial or primary follicles. Granulosa cells show the most intense signals of localization in preantral follicles, as in hamster (Roy et al. 1987) and rat (Clarke et al. 1993) ovary. Since granulosa cells are highly proliferative in preantral follicles, and PRL is a mitogen in granulosa cells (Roy \& Greenwald 1988) as in other cells (Das \& Vonderhaar 1995, Olazabal et al. 2000), the hormone might stimulate their proliferation at this stage to promote early follicular development, as reported in prepubertal rats (Advis et al. 1981, Kawagoe \& Hiroi 1989, Peluso 1989). In preantral follicles, PRLrs appeared in theca cells once they became organized in several layers. Then, during follicular development, PRL would first act on stromal and granulosa cells, and at the end of the preantral stage it could also exert its actions on theca, just prior to antrum formation. From antrum formation, until the follicle reached $2-3 \mathrm{~mm}$ in diameter (gonadotropin-responsive follicle in sheep; Scaramuzzi et al. 1993), PRLrs were evenly localized in granulosa 
and theca cells. During this phase of growth, PRL might then act on both cell types, possibly modulating androgen biosynthesis in theca cells (McNeilly et al. 1982, Magoffin \& Erickson 1982), and estradiol and progesterone in granulosa cells (Fortune \& Vincent 1986, Fortune et al. 1986, Gitay-Goren et al. 1989, Krasnow et al. 1990, Villanueva et al. 1996). Since androgens are the substrate for estradiol synthesis in granulosa cells, effects of PRL on biosynthesis of thecal androgens might represent an interesting modulator action of this hormone on the paracrine interaction between both cell types. Interestingly, as follicles grew beyond the gonadotropin-responsive phase to the gonadotropin-dependent stage $(4-5 \mathrm{~mm})$, granulosa cells gradually lost immunoreactivity for PRLrs in a different way for each isoform. In contrast to the scattered loss of short PRLrs, decreased immunoreactivity for the long PRLr primarily occurred in mural granulosa cells, whereas antral granulosa cells were positive for long PRLr until the transition to ovulatory follicle. This finding is in agreement with the lack of PRLrs in mural cells of rat antral follicles (Dunaif et al. 1982) and is consistent with the occurrence of two granulosa cell subpopulations that differ in cell sizes and hormonal responsiveness (Rao et al. 1991, Sanbuissho et al. 1993). During follicular development granulosa cells differentiate into antral and mural cells; antral cells are larger than mural cells, are placed close to the antrum, appear to be involved in the synthesis of estradiol and progesterone, and lose their ability to proliferate earlier than mural cells. Mural cells are placed next to the basal membrane, keep their proliferative potential, and are poorly or not responsive to gonadotropins. Our results are in agreement with a different spatial distribution of two granulosa cell populations differing in potential responsiveness to PRL. Loss of long PRLr in mural cells makes them unresponsive to PRL, since formation of long isoform homodimers is required for PRL to exert its actions. This might represent a critical step of granulosa cell differentiation, when follicles reach the gonadotropin-dependent stage. The loss of PRLrs extended to antral granulosa cells of the ovulatory follicle where only some cumulus cells had PRLrs, along with moderate signals in theca. This particular feature might be a relevant part of the mechanisms of selection of the ovulatory follicle, if we consider that reported effects of PRL on estradiol secretion in granulosa are, in general, inhibitory (Krasnow et al. 1990), and in sheep, plasma PRL levels increase during the follicular phase (Reeves et al. 1970). Lack of PRLrs in granulosa cells of the selected follicle would guarantee sustained estradiol secretion from this follicle during the preovulatory phase, at the time of estrus.

Our results showed that, in general, both PRLrs shared the same cell localization, indicating their coexpression as in rat ovary (Clarke et al. 1993). Therefore, in each cell, the relative expression of both isoforms determines the real responsiveness to PRL. As in earlier studies (Clarke et al. 1993), changes in expression of each PRLr were determined on whole ovaries, not in individual follicles, for practical reasons since the time involved in dissection of individual follicles from all ovaries would have led to extensive RNA degradation. However, in Spanish Merino ewes the mean number of follicles of 2,3 , and $4-5 \mathrm{~mm}$ does not vary over the last 7 days of the estrous cycle, including the onset of estrus (López Sebastián et al. 1997). This time interval comprises days 10 and 15 of the estrous cycle, when we obtained ovaries at mid-luteal and early follicular phases respectively. In addition, at estrus (day 0 in our study), a preovulatory follicle $(\geq 6 \mathrm{~mm})$ continues growth in one ovary, along with a non-significant decrease in the number of antral follicles (López Sebastián et al. 1997). All of this indicates that the variations found in the current study in expression of long and short PRLrs - over days 10,15 and 0 of the estrous cycle - do not result from differences in the number of follicles of each of those developmental stages, but are changes related to the day of the cycle. The expression of short PRLr might be constitutive, since it was similar at the time of estrus, at mid-luteal phase and at the early follicular phase. In contrast, the expression of long PRLr exhibited remarkable changes throughout the estrous cycle, indicating that it is closely regulated by hormones and/or local factors. Long PRLr expression was up-regulated at the time of estrus, when PRLrs were abundantly localized in granulosa cells of all preantral and antral follicles up to $2-3 \mathrm{~mm}$, in stromal cells surrounding primordial and primary follicles, and moderately localized in theca of all antral follicles. Therefore, it can be hypothesized that at the time of estrus the expression of long PRLr might increase in these cells, possibly due to an up-regulatory action of estradiol, as in granulosa cells of rat in culture (Russell \& Richards 1999) and in the mammary gland of estradiol-treated ovariectomized mice (Mizoguchi et al. 1997), in which the expression of the short PRLr also remained unchanged. This would make preantral and gonadotropin-responsive follicles highly responsive to PRL at the time of estrus, when plasma concentrations of PRL rise in sheep. In support of this view, there is evidence that PRL might prevent early atresia of gonadotropin-responsive follicles during the follicular phase of the estrous cycle in Merino ewes (Picazo et al. 2000). Provided that only binding of PRL to homodimers of the long PRLr has been recognized to mediate the actions of this hormone on target cells (Chang \& Clevenger 1996, Berlanga et al. 1997, Perrot Applanat et al. 1997), PRL would principally act on potentially responsive ovarian cells around the time of estrus, when the expression of the long form is much greater than the short one. The expression of the long PRLr at levels similar to or lower than the short form would increase the opportunities to form inactive heterodimers, which according to our results would occur in ovaries at mid-luteal and early follicular phases. 
From our results we conclude that in sheep ovary, the potential responsiveness to PRL is at a maximum in stromal and granulosa cells at the initial stages of follicular development, is moderate in granulosa and theca cells of antral follicles, gradually decreases in granulosa cells and is lost in ovulatory follicles. The possibilities of potentially responsive ovarian cells being a target of PRL may increase at estrus, when long PRLr expression is markedly augmented.

\section{Acknowledgements}

This work was supported by a UCM grant (PR64/99-8523). We thank Dr Pat Ingleton from the Institute of Endocrinology at Sheffield University for kindly donating the antibodies against long and short rat prolactin receptors. We also wish to thank Dr Tortonese from Bristol University for his expert advice. We are indebted to Dr López Sebastián for his logistic support and for providing the ewes used in this study.

\section{References}

Advis JP, Richards JS \& Ojeda SR 1981 Hyperprolactinemia-induced precocious puberty: studies on the mechanism(s) by which prolactin enhances ovarian progesterone responsiveness to gonadotrophins in prepubertal rats. Endocrinology 108 1333-1342.

Anthony RV, Smith GW, Duong A, Pratt SL \& Smith MF 1995 Two forms of the prolactin receptor messenger ribonucleic acid are present in ovine fetal liver and adult ovary. Endocrine 3 291-295.

Bacich AJ, Rohan RM, Norman RJ \& Rodgers RJ 1994 Characterization and relative abundance of alternatively spliced luteinizing hormone receptor messenger ribonucleic acid in the ovine ovary. Endocrinology $135735-744$.

Ben-Jonathan N, Mershon JL, Allen DL \& Steinmetz RW 1996 Extrapituitary prolactin: distribution, regulation, functions, and clinical aspects. Endocrine Reviews 17 639-669.

Berlanga JJ, García Ruiz JP, Perrot-Applanat M, Kelly PA \& Edery M 1997 The short form of the prolactin (PRL) receptor silences PRL induction of the $\beta$-casein gene promoter. Molecular Endocrinology 11 1449-1457.

Bignon C, Binart N, Ormandy C, Schuler LA, Kelly PA \& Djiane J 1997 Long and short forms of the ovine prolactin receptor: DNA cloning and genomic analysis reveal that the two forms arise by different alternative splicing mechanisms in ruminants and in rodents. Journal of Molecular Endocrinology 19 109-120.

Bispham J, Heasman L, Clarke L, Ingleton PL, Stephenson T \& Symonds ME 1999 Effect of maternal dexamethasone treatment and ambient temperature on prolactin receptor abundance in brown adipose and hepatic tissue in the foetus and new-born lamb. Journal of Neuroendocrinology 11 849-856.

Bjurulf E, Selstam G \& Olofsson JL 1994 Increased LH receptor mRNA and extended corpus luteum function induced by prolactin and indomethacin treatment in vivo in hysterectomised pseudopregnant rats. Journal of Reproduction and Fertility 102 139-145.

Buckley AR, Putnam CW \& Russell DH 1984 Rapid elevation of plasminogen activator activity in rat tissues by prolactin. Biochemical and Biophysical Research Communications 122 1005-1011.

Buckley AR, Putnam CW \& Russell DH 1985 Prolactin is a tumour promoter in rat liver. Life Science 37 2569-2575.

Budge H, Bispham H, Dandrea J, Evans E, Heasman L, Ingleton PM, Sullivan C, Wilson V, Stephenson T \& Symonds ME 2000 Effect of maternal nutrition on brown adipose tissue and its prolactin receptor status in the fetal lamb. Pediatric Research 47 781-786.

Budge H, Dandrea J, Mostyn A, Evens Y, Watkins R, Sullivan C, Ingleton P, Stephenson T \& Symonds ME 2003 Differential effects of fetal number and maternal nutrition in late gestation on prolactin receptor abundance and adipose tissue development in the neonatal lamb. Pediatric Research 53 (2) 302-308.

Chang W-P \& Clevenger CV 1996 Modulation of growth factor receptor function by isoform heterodimerization. PNAS 93 5947-5952.

Clarke DL, Arey BJ \& Linzer DIH 1993 Prolactin receptor messenger ribonucleic acid expression in the ovary during the rat estrous cycle. Endocrinology 133 2594-2603.

Clarke LA, Wathes DC \& Jabbour HN 1997 Expression and localization of prolactin receptor messenger ribonucleic acid in red deer ovary during the estrous cycle and pregnancy. Biology of Reproduction 57 865-872.

Das R \& Vonderhaar BK 1995 Transduction of prolactin's (PRL) growth signal through both long and short forms of the PRL receptor. Molecular Endocrinology 9 1750-1759.

Denamur R, Martinet J \& Short R 1973 Pituitary control of the ovine corpus luteum. Journal of Reproduction and Fertility 32 207-220.

Dunaif AE, Zimmerman EA, Friesen HG \& Frantz AG 1982 Intracellular localization of prolactin receptor and prolactin in the rat ovary by immunocytochemistry. Endocrinology 1101465.

Fortune JE \& Vincent SE 1986 Prolactin modulates steroidogenesis by rat granulosa cells. I. Effects on progesterone. Biology of Reproduction 35 84-91.

Fortune JE, Wissler RN \& Vincent SE 1986 Prolactin modulates steroidogenesis by rat granulosa cells. II. Effects on estradiol. Biology of Reproduction 35 92-99.

Gibori G 1992 The corpus luteum of pregnancy. In The Ovary, pp 261-317. Eds EY Adashi \& PCK Leung. New York: Raven Press.

Gitay-Goren H, Lindenbaum ES \& Kraiem Z 1989 Prolactin inhibits hCG-stimulated steroidogenesis and cAMP accumulation, possibly by increasing phosphodiesterase activity, in rat granulosa cell cultures. Molecular and Cellular Endocrinology 61 69-76.

Goffin V, Binart N, Clement-Lacroix P, Bouchard B, Bole-Feysot C, Edery M, Lucas BK, Touraine P, Pezet A, Maaskant R, Pichard C, Helloco C, Baran N, Favre $H$, Bernichtein S, Allamando A, Ormandy C \& Kelly PA 1999 From the molecular biology of prolactin and its receptor to the lessons learned from knockout mice models. Genetic analysis: Biomolecular Engineering 15 189-201.

Jonassen JA, Baker SP \& McNeilly AS 1991 Long-term hyperprolactinaemia reduces basal but not androgen-stimulated oestradiol production in small antral follicles of the rat ovary. Journal of Endocrinology 129 357-362.

Jones PBC, Valk ChK \& Hsueh AJW 1983 Regulation of progestin biosynthetic enzymes in cultured rat granulosa cells: effects of prolactin, $\beta_{2}$-adrenergic agonist, human chorionic gonadotrophin and gonadotrophin releasing hormone. Biology of Reproduction 29 $572-585$.

Kawagoe S \& Hiroi M 1989 Further evidence that prolactin controls the prepubertal sexual development in the female rat. Gynaecologic and Obstetric Investigation 27 197-200.

Kermabon AY, Belair L, Theau-Clément $M$, Salesse R \& Djiane J 1994 Effects of anoestrus and bromocryptine treatment on the expression of prolactin and $\mathrm{LH}$ receptors in the rabbit ovary during lactation. Journal of Reproduction and Fertility 102 131-138.

Kiziridou AD, Toliou T, Stefanon D \& Agnantis N 2002 U-PA expression in benign, borderline and malignant ovarian tumours. Anticancer Research 22 985-990.

Krasnow JS, Hickey GJ \& Richards JS 1990 Regulation of aromatase mRNA and estradiol biosynthesis in rat ovarian granulosa and luteal cells by prolactin. Molecular Endocrinology 4 13-21.

López Sebastián A, González de Bulnes A, Santiago Moreno J, Gómez Brunet A, Townsend EC \& Inskeep EK 1997 Patterns of follicular development during the estrous cycle in monovular Merino del Pais ewes. Animal Reproduction Science 48 279-291.

McNeilly AS, Glasier A, Jonassen J \& Howie PW 1982 Evidence for direct inhibition of ovarian function by prolactin. Journal of Reproduction and Fertility 65 559-569.

Magoffin DA \& Erickson GF 1982 Prolactin inhibition of luteinizinghormone stimulated androgen synthesis in ovarian interstitial cells 
cultured in defined medium: mechanism of action. Endocrinology $1112001-2007$.

Matsuyama S, Chang KT, Kanuka H, Ohnishi M, Ikeda A, Nishihara M \& Takahashi M 1996 Occurrence of deoxyribonucleic acid fragmentation during prolactin-induced structural luteolysis in cycling rats. Biology of Reproduction 54 1245-1251.

Mizoguchi Y, Kim J-Y-, Enami J \& Sakai S 1997 The regulation of the prolactin receptor gene expression in the mammary gland of early pregnant mouse. Endocrine Journal 44 53-58.

Murray SC, Keeble SC, Muse KN \& Curry TE Jr 1996 Regulation of granulosa cell-derived ovarian metalloproteinase inhibitor(s) by prolactin. Journal of Reproduction and Fertility 107 103-108.

Nagano M \& Kelly PA 1994 Tissue distribution and regulation of rat prolactin receptor gene expression: quantitative analysis by polymerase chain reaction. Journal of Biological Chemistry 269 $13337-13345$

Olazabal I, Muñoz J, Ogueta S, Obregón E \& García-Ruiz JP 2000 Prolactin (PRL)-PRL receptor system increases cell proliferation involving JNK (c-Jun amino terminal kinase) and AP-1 activation: inhibition by glucocorticoids. Molecular Endocrinology $\mathbf{1 4}$ 564-575.

Ormandy CJ, Camus A, Barra J, Damotte JD, Lucas B, Buteau H, Edery M, Brousse N, Babinet C, Binart N \& Kelly PA 1997 Null mutation of the prolactin receptor gene produces multiple reproductive defects in the mouse. Genes and Development 11 $167-178$.

Peluso JJ 1989 Role of the peripubertal pattern of FSH, LH, and PRL secretion in regulating in vitro steroidogenesis and follicular growth within juvenile rat ovaries. Journal of Reproduction and Fertility 86 705-711.

Perrot-Applanat M, Gualillo O, Pezet A, Vicent V, Edery M \& Kelly PA 1997 Dominant negative and cooperative effects of mutant forms of prolactin receptor. Molecular Endocrinology 11 1020-1032.

Picazo RA, González de Bulnes A, Gómez Brunet A, del Campo A, Granados B, Tresguerres J \& López Sebastián 2000 Effects of bromocriptine administration during the follicular phase of the estrous cycle on prolactin and gonadotrophin secretion and follicular dynamics in Merino monovular ewes. Journal of Reproduction and Fertility $120177-186$.

Rao IM, Allsbrook WC Jr, Conway BA, Martinez JE, Beck JR, Pantazis CG, Mills TM, Anderson E \& Mahesh VB 1991 Flow cytometric analysis of granulosa cells from developing rat follicles. Journal of Reproduction and Fertility 91 521-530.

Reeves JT, Arimura S \& Schally AB 1970 Serum levels of prolactin and luteinizing hormone $(\mathrm{LH})$ in the ewe at various stages of the estrous cycle. Procceedings of the Society of Experimental Biology and Medicine 134 938-942.

Riley SC, Gibson AH, Leask R, Mauchline DJ, Pedersen HG \& Watson ED 2001 Secretion of matrix metalloproteinases 2 and 9 and tissue inhibitor of metalloproteinases into follicular fluid during follicle development in equine ovaries. Reproduction 121 553-560.

Roy SK \& Greenwald GS 1988 In vitro effects of follicle stimulating hormone, luteinizing hormone, and prolactin on follicular deoxyribonucleic acid synthesis in the hamster. Endocrinology 122 952-958.
Roy SK, Wang SC \& Greenwald GS 1987 Radioreceptor and autoradiographic analysis of $\mathrm{FSH}, \mathrm{hCG}$, and prolactin binding sites in primary to antral hamster follicles during the periovulatory period. Journal of Reproduction and Fertility $79307-313$.

Russell DL \& Richards JS 1999 Differentiation-dependent prolactin responsiveness and Stat (signal transducers and activators of transcription) signaling in rat ovarian cells. Molecular Endocrinology 13 2049-2064.

Sanbuissho A, Lee GY \& Anderson E 1993 Functional and ultrastructural characteristics of two types of rat granulosa cell cultured in the presence of FSH or transforming growth factor alpha (TGFalpha). Journal of Reproduction and Fertility 98 367-376.

Scaramuzzi RJ, Adams NR, Baird DT, Campbell BK, Downing JA, Findlay JK, Henderson KM, Martin GB, McNatty KP, McNeilly AS \& Tsonis CG 1993 Model for follicle selection and the determination of ovulation rate in the ewe. Reproduction Fertility and Development 5 459-478.

Song L, Ryan PL, Plater DG \& Coomber BL 2001 Effects of relaxin on matrix remodelling enzyme activity of cultured equine ovarian stromal cells. Animal Reproduction Science $\mathbf{6 6}$ 239-255.

Tortonese DJ, Brooks J, Ingleton PM \& McNeilly AS 1998 Detection of prolactin receptor gene expression in the sheep pituitary gland and visualization of the specific translation of the signal in gonadotrophs. Endocrinology 139 5215-5223.

Tsai-Morris C-H, Ghosh M, Hirshfield AN, Wise PM \& Brodie AMH 1983 Inhibition of ovarian aromatase by prolactin in vivo. Biology of Reproduction 29 342-346.

Veldhuis JD, Klase P \& Hammond J 1980 Divergent effects of prolactin upon steroidogenesis by porcine granulosa cells in vitro: influence of cytodifferentiation. Endocrinology 107 42-46.

Villanueva LA, Mendez I, Ampuero S \& Larrea F 1996 The prolactin inhibition of follicle-stimulating hormone-induced aromatase activity in cultured rat granulosa cells is in part tyrosine kinase and protein kinase-C dependent. Molecular Human Reproduction 2 $725-731$.

Wiseman BS \& Werb Z 2002 Stromal effects on mammary gland development and breast cancer. Science 296 1046-1049.

Yoshida Y 1987 Studies on the regulation of steroid biosynthesis in the rat ovary. Acta Obstetrica et Gynaecologica Japonica 39 1537-1544.

Yoshimura Y, Maruyama K, Shiraki M, Kawakami S, Fukushima M \& Nakamura Y 1990 Prolactin inhibits plasminogen activator activity in the preovulatory follicles. Endocrinology 126 631-636.

Zabala MT \& García-Ruiz JP 1989 Regulation of expression of the messenger ribonucleic acid encoding the cytosolic form of phosphoenolpyruvate carboxykinase in liver and small intestine of lactating rats. Endocrinology 125 2587-2593.

Received 14 June 2003

First decision 28 August 2003

Revised manuscript received 30 June 2004

Accepted 2 July 2004 